\title{
REKONSTRUKSI ASAS LEGALITAS DALAM HUKUM PIDANA BERDASARKAN PRINSIP KEADILAN
}

\author{
Fransiskus Saverius Nurdin \\ Staff Pengajar Fakultas Hukum \\ Universitas Wira Wacana Sumba \\ Korespondensi: francisraffieitan@hotmail.com
}

\begin{abstract}
Abstrak
Salah satu prinsip penting dalam hukum pidana terdapat di dalam asas legalitas yang menyatakan bahwa, "tidak ada suatu perbuatan yang dapat dipidana kecuali atas kekuatan undang-undang pidana yang ada sebelum perbuatan itu dilakukan." Asas legalitas merupakan manifestasi sisi negatif dari hukum itu sendiri. Asas Legalitas tidak pada posisi sebagai bagian dari hukum yang sebenarnya (sisi positif) di mana hukum bukanlah sekedar perkara undang-undang atau daftar peraturan melainkan sesuatu yang tertanam pada jiwa manusia, sesuatu yang merupakanbagian integral dari pengalaman manusia. Asas legalitas lahir sebagai klimaks perjuangan manusia yang menghendaki adanya hukum pidana yang tertulis dalam bentuk undang-undang, untuk membatasi kesewenangan penguasa dan hakim yang menetapkan hukum menurut perasaan mereka sendiri. Penelitian ini merupakan penelitian hukum (legal research) yang menawarkan pengubahan sisi negatif dari asas legalitas dengan merekonstruksi rumusanya menjadi "tiada perbuatan pidana tanpa pidana menurut perundang-undangan pidana dan hukum yang hidup dalam masyarakat (the living law)".
\end{abstract}

Kata-kata Kunci: Asas Legalitas; Undang-undang; Keadilan; Rekonstruksi.

\begin{abstract}
One of the key principles of criminal law contained in the principle of legality, which asserts that "there is no punishable crime without any criminal law that existed before the act was committed." The principle of legality is a manifestation of the negative side of the law itself. The principle of legality is not in the position as part of the actual law (positive side) where the law is not just contained in written law and regulations, but rather embedded in the human spirit and as an integral part of the human experience. The principle of legality emerged as the climax of human struggle that requires the existence of written criminal law in the form of legislation, to limit the abuse of authority and the judge who establishes the law according to their own belief. This research is a legal research that offers the alteration of the negative side of the principle of legality by reconstructing its formulation that "there is no punishable crime without any crime previously formulated in the criminal law and the laws that live in the community (the living law)".
\end{abstract}

Key Words: Principle of Legality; Statute; Justice; Reconstruction. 


\section{PENDAHULUAN}

Asas legalitas pertama-tama mempunyai bentuk sebagai undang-undang adalah dalam konstitusi Amerika 1776 dan sesudah itu dalam Pasal 8 Declaration de droits de I' homme et ducitoyen 1789: nul ne peut etre puniqu'en vertu d'une loi etabile et promulguee anterieurement au delit et legalement appliquee. Asas ini selanjutnya dimasukkan ke dalam Pasal 4 Code Penal Perancis yang menentukan Nulle cotraventtion, nul delit, nul crimene peuvent entter punis de peinesqui n'etaient pas prononcees par lai loa avant qu'ils fussent comnis" artinya: Tidak bertentangan dengan ketentuan yang ada, tiada delik, tiada kejahatan jika tidak ada ancaman pidana yang dinyatakan dalam undangundang terlebih dahulu.

Dari Code Penal Perancis inilah, asas tersebut kemudian dimasukkan dalam Pasal 1 ayat (1) Wetboek van Strafrecht di Negeri Belanda yang dengan tegas menyatakan, "Geen feit is strafbaar dan uitkraftvan eenedaaraan voorafgegane wetelijke strafbepaling“. Selanjutnya asas tersebut dimuat dalam Pasal 1 ayat (1) KUHP Indonesia. ${ }^{1}$

Asas Legalitas dibentuk untuk kepentingan umum dan untuk menjamin hak-hak semua warga masyarakat secara lebih baik dan bukan pengakuan terhadap individualisme. Dasar umum perlu tidaknya suatu hukuman itu dijatuhkan dan tentang adanya suatu hukuman itu sendiri adalah kebutuhan untuk memelihara kebebasan semua orang secara timbal balik, dengan meniadakan niat orang untuk melakukan tindakan yang bersifat melanggar hukum. Merupakan suatu asas yang penting bagi pemberian ancaman hukuman didalam hukum pidana, yaitu bahwa setiap penjatuhan hukuman oleh hakim haruslah merupakan suatu akibat hukum dari suatu ketentuan undang-undang yakni dengan maksud menjamin hak-hak yang ada pada setiap orang. ${ }^{2}$

Suatu perbuatan tidak dikualifikasikan sebagai perbuatan pidana jika tidak dilarang dalam undang-undang pidana. Perbuatan pidana adalah perbuatan yang dilarang oleh undangundang pidana, suatu perbuatan yang onwetmatig (bertentangan dengan undang-undang) yang dikenal sebagai mala prohibita. Perbuatan pidana yang belum atau tidak dilarang oleh oleh undang-undang dikenal sebagai crimina extra ordinaria, ${ }^{3}$ suatu perbuatan yang onrechmatig (bertentangan dengan hukum). Diantara crimina extra ordinaria dikenal dengan nama crimina stellionatus perbuatan jahat atau durjana. ${ }^{4}$

Tuntutan pidana hanya ditujukan terhadap perbuatan yang dikualifikasikan sebagai mala prohibita. Sebaliknya tuntutan pidana tidak dapat ditujukan

Eddy O.S. Hiarej, 'Asas Legalitas dan Perkembangannya dalam Hukum Pidana' (Pelatihan Hukum Pidana dan Kriminologi, Universitas Gadjah Mada, Yogyakarta, 2014) 12.

Van Bemmelen, Ons Strafrecht: Algemeen del het Materiel Strafrecht (H.D. Tjeenk Willink 1971) 55. Moeljatno, Asas-Asas Hukum Pidana (Rineka Cipta 2000) 24.

Ibid. 
terhadap crimina extra ordinaria meskipun menimbulkan kerugian yang bagi korban, hanya karena belum diatur atau tidak dilarang oleh undangundang pidana. Dari perspektif Asas legalitas mala prohibita merupakan perbuatan yang strafbaar(dapat dipidana) dan crimina extra ordinaria adalah strafwaardig (patut dipidana) dan bukan strafbaar karena tidak dilarang oleh undang-undang pidana. Secara prinsip dilarang mendefinisikan suatu perbuatan sebagai "mala prohibita" dengan cara mengkostruksikan suatu perbuatan sebagai perbuatan pidana diluar yang dilarang oleh undangundang. Prinsip ini disebut "prinsip non analogi."

Undang-undang pidana yang harus diberlakukan untuk menuntut suatu perbuatan adalah undang-undang pidana yang sudah ada dan berlaku pada saat perbuatan dilakukan (lex temporis delictiatau existing penal law). Undang-undang pidana setelah perbuatan dilakukan (ex post facto penal law) dilarang untuk diterapkan. Dilarang memberlakukan undang-undang pidana secara surut (retroaktif) terhadap perbuatan yang telah dilakukan sebelum undang-undang tersebut dibuat. Prinsip ini dikenal sebagai "prinsip non retroaktif'.

Schaaffmeister dan kawan-kawan berpendapat bahwa berlakunya Asas
Legalitas bertujuan agar undangundang pidana melindungi rakyat dari pelaksanaan kekuasan tanpa batas oleh pemerintah. Ini yang dinamakan fungsi melindungi dari undang-undang pidana. Undang-undang pidana juga mempunyai fungsi instrumental yaitu bahwa pelaksanaan kekuasan pemerintah tegas-tegas diperbolehkan dalam batas-batas yang ditentukan oleh undang-undang. ${ }^{5}$

Adanya terma legisme atau legalistic menimbulkan kontradiksi antara hukum yang sebenarnya dan hukum undang-undang. Perundangan sangat jauh dari hukum. Hukum (ius) adalah baik dan adil tanpa perintah, sedangkan perundangan (leges) dihasilkan dari penerapan kedaulatan dari orang yang memerintah. ${ }^{6}$

Memang dalam literatur-literatur klasik dikemukakan antinomi antara kepastian hukum dan keadilan ${ }^{7}$. Kedua hal tersebut sangat mustahil dapat diwujudkan dalam situasi yang bersamaan. Oleh karena itu dalam hal ini hukum itu bersifat kompromi yaitu dengan mengorbankan keadilan demi mencapai kepastian hukum. ${ }^{8}$ Dalam menghadapi antinomi tersebut peran penerap hukum sangat diperlukan. Peranan tersebut akan terlihat saat penerap hukum dihadapkan pada persoalan yang konkret. Disitu penerap hukum harus mampu untuk melaku-

\footnotetext{
D. Schaffmeister et.al., Hukum Pidana (Liberty 1995) 4.

Carl Joachim Friedrich, Filsafat Hukum dalam Perspektif Historis (Nusa Media 2010) 75-76.

Peter Mahmud Marzuki, Pengantar Imu Hukum (Kencana Prenada Media Group 2013) 139.

P. van Dijk et.al., Van Apeldoorn's Inleiding tot de Studie van het Nederlands Recht (W.E.J. TjeenkWillink 1985) 15.
} 
kan alternatif mana yang harus dikorbankan, kepastian hukum ataukah keadilan. Dan yang menjadi acuan adalah moral. Jika kepastian hukum yang dikedepankan penerap hukum harus pandai-pandai memberikan interprestasi terhadap undang-undang.

Betapapun tujuan hukum adalah untuk menciptakan damai sejahtera dalam hidup bermasyarakat. Sehingga perlu diingat kembali pernyataan Ulpianus bahwa: "perintah hukum adalah hidup jujur, tidak merugikan sesama manusia, dan setiap orang mendapat bagiannya. Perlu juga kita merefleksi pendapat Bellefroid yang menyatakan:

Hukum adalah berusaha untuk memenuhi kebutuhan jasmani, kejiwaan, dan rohani masyarakat, sesuai dengan keadaan masyarakatnya, atau juga meningkatkan kemampuan individu dalam hidup bermasyarakat. Dengan demikian, apabila dikatakan bahwa masyarakat dalam keadaan tertib berarti setiap orang di dalam masyarakat tersebut dapat mengembangkan keadaannya baik secara jasmani, pikiran maupun rohaninya. ${ }^{9}$

Merupakan suatu kenyataan bahwa dalam hidup bermasyarakat diperlukan aturan-aturan yang bersifat umum. Betapapun setiap kepentingan yang ada dalam masyarakat dipertimbangkan untuk dituangkan didalam aturan yang bersifat umum agar kepentingan-kepentingan itu dilindungi dan sedemokratis apapun kehidupan bernegara tidaklah mungkin semua aturan-aturan itu dapat mengakomodasi semua kepentingan tersebut. Pada masyarakat yang modern aturan yang bersifat umum tempat dituangkannya perlindungan kepentingan itu adalah undang-undang. ${ }^{10}$

Aturan hukum, baik berupa undangundang maupun hukum tidak tertulis dengan demikian berisi aturan yang bersifat umum yang menjadi pedoman bagi individu bertingkah laku dalam hidup bermasyarakat, baik dalam hubungan dengan sesama individu maupun dengan masyarakat. Aturan-aturan itu menjadi batasan dalam masyarakat dalam membebani atau melakukan tindakan terhadap individu. Adanya aturan semacam itu dan pelaksanaan aturan tersebut menimbulkan kepastian hukum. Dengan demikian kepastian hukum mengandung dua pengertian yaitu: pertama adanya aturan yang bersifat umum yang membuat individu mengetahui perbuatan apa yang boleh atau tidak boleh dilakukan, kedua keamanan hukum bagi individu dari kesewenangan pemerintah karena dengan adanya aturan yang bersifat umum itu individu dapat mengetahui apa saja yang boleh dibebankan atau dilakukan oleh negara terhadap individu. ${ }^{11}$

Legalitas mencakup prinsip negatif dan positif. Prinsip negatif legalitas menyatakan bahwa pertimbangan utama dari sistem hukum adalah untuk melindungi warga negara dari negaranya

J.H.P. Bellefroid et.al., Inleiding tot de Rechtwetenschap in Nederlands (Utrecht 1952) 3.

Peter Mahmud Marzuki, Op.Cit. 136.

Ibid. 137. 
yang hendak memaksakan kehendaknya kepada warga negara tersebut. Prinsip positif legalitas menekankan konsistensi dan kelengkapan dalam mengaplikasikan hukum yang mengharuskan sebuah negara untuk menghukum orang yang bersalah. Pembedaan antara prinsip positif dan negatif legalitas hanyalah satu pembedaan yang harus diingat ketika membicarakan soal legalitas dan keadilan. Legalitas akan merujuk pada hukum positif, sedangkan keadilan tidak semata-mata berdasarkan hukum positif tetapi juga moralitas. ${ }^{12}$

\section{METODE PENELITIAN}

Dalam rangka memperoleh kemudian menganalisis setiap informasi yang bersifat ilmiah, tentunya dibutuhkan suatu metode dengan tujuan agar suatu karya ilmiah itu memiliki susunan yang sistematis, terarah dan konsisten. ${ }^{13}$ Penelitian ini adalah penelitian hukum dengan pertimbangan bahwa titik tolak penelitian adalah mengkaji Asas Legalitas. Pendekatan yang digunakan dalam penelitian adalah pendekatan filsafat (philosophy approach), pendekatan undang-undang (statue approach), pendekatan sejarah (historys approach).

Bahan hukum yang digunakan dalam penelitian ini disesuaikan adalah

1. Bahan hukum primer, yaitu bahan hukum yang mengikat dan terdiri dari norma dasar yaitu KUHP, UU
Darurat tahun 1951, PERPPU No.1 Tahun 2002, UU No.15 Tahun 2003, RUU KUHP tahun 2012,

2. Bahan hukum sekunder, yaitu bahanbahan yang memberi penjelasan mengenai sumber data primer seperti, hasil penelitian dari para Jurist ${ }^{14}$, buku ilmu hukum, jurnal hukum.

3. Bahan hukum tertier, yaitu bahan hukum yang memberikan petunjuk maupun penjelasan terhadap bahan hukum primer, dan sekunder. Contohnya website, ensiklopedia, kamus. ${ }^{15}$

\section{PEMBAHASAN}

\section{Legalitas dan Keadilan}

Menurut makna universal hukum, hukum ialah mewujudkan keadilan dalam hidup bersama manusia. Makna ini tercapai dengan dimasukkanya prinsip-prinsip keadilan bagi kehidupan bersama itu. Maka menurut pandangan orang, hukum yang sebenarnya adalah hukum yang positif yang merupakan realisasi dari prinsip keadilan. Harus diakui bahwa orang yang berpandangan empiris tidak sampai pada pandangan ini. Mereka mendapat pengertian tentang hukum dari apa yang terjadi dalam pembentukan hukum dalam undangundang. Dengan ini mereka memastikan bahwa hukum berasal dari suatu pemerintahan yang sah dalam suatu negara yang berdaulat. ${ }^{16}$

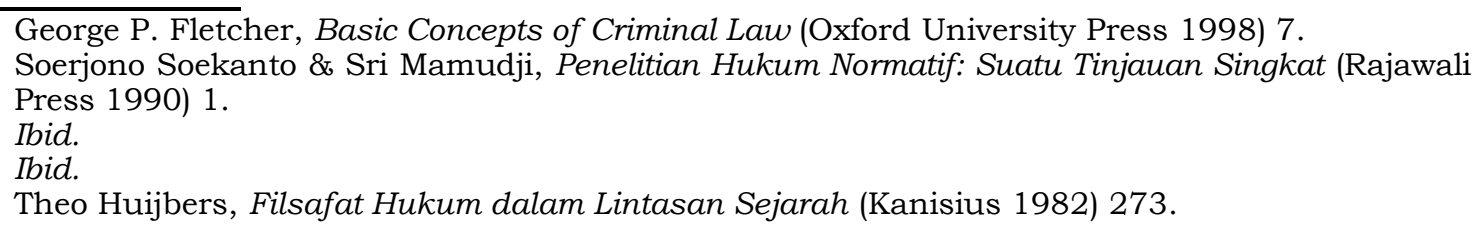


Pemerintah itu meneliti situasi, melihat kebutuhan akan peraturan tertentu, lalu mnegesahkan peraturan tersebut. dapat dipastikan juga bahwa pembuatan itu dapat dipengaruhi oleh beberapa faktor. Sudah barang tentu situasi historis dan politik masyarakat terlebih dahulu menjadi dasar pertimbangan. Kemudian juga ideologi negara dapat menjadi petunjuk dalam membentuk undang-undang. Mungkin juga kepentingan pribadi ikut menentukn isi undang-undang. Tetapi pengertian tentang hukum sebagai norma suatu hidup bersama yang adil tidak masuk pertimbangan mereka. ${ }^{17}$

Walaupun makna hukum sebagai suatu aturan yang adil tidak diperoleh melalui penyelidikan ilmiah, pada diri setiap orang tetap ada keyakinan bahwa hukum ada hubungan dengan yang seharusnya. Dalam hati manusia hiduplah keinsyafan yang membawa orang pada suatu penilaian faktor-fakor yang berperanan dalam pembentukan hukum.

Kadang-kadang juga terjadi bahwa undang-undang yang dahulu cocok dengan situasi masyarakat karena perkembangan sosial makin menjauhkan diri dari rasa keadilan yang hidup dalam hati orang. Atau juga terjadi bahwa para penguasa mempunyai niat yang sungguhsungguh untuk membuat undangundang yang adil tetapi usaha ini gagal. Pada kenyataanya undang-undang itu ditaati pada permulaan, tetapi kemudian jurang antara hukum positif dan prinsip-prinsip keadilan menjadi nyata.
Akibatnya peraturan yang ditentukan kehilangan artinya sebagai hukum dan mungkin tidak akan ditaati lagi. Bila perkembangan semacam ini cukup disadari oleh orang-orang yang menetapkan hukum mereka itu akan menyetujui bahwa hukum positif menjadi hukum yang mati. ${ }^{18}$

Hukum hanya dipandang sebagai hukum kalau tidak bertentangan dengan prinsip keadilan. Konsekuensi logisnya adalah peraturan yang tidak adil bukanlah hukum yang sebenarnya. Tetapi kalau suatu peraturan kehilangan maknanya sebagai hukum, maka peraturan itu tidak mewajibkan lagi sehingga, tidak boleh ditaati. Aquinas menyatakan "pemberontakan terhadap tata hukum yang tidak adil sering kali tidak diizinkan karena bahaya huru-hara dan anarkhi." Walaupun demikian tetap benar bahwa hukum yang tidak adil kehilangan artinya sebagai hukum, sekalipun peraturannya terus ditaati. Peraturan ini ditaati tidak oleh karena memiliki kekuatan hukum, tetapi oleh karena orang yang menetapkannya adalah penguasa. Maka dengan ini perbedaan antara hukum dan kekuasaan telah hilang.

Dalam konteks ketaatan seperti di atas peneliti melihat bahwa dalam hal ini orang mentaati peraturan itu (yang tidak adil) karena adanya ketakutan terhadap penguasa bukan ketaatan dari dalam sikap batinnya (moral).

Memang dalam aplikasi hukum sangat sulit membedakan hukum yang $\begin{array}{ll}17 & \text { Ibid. } 274 \\ 18 & \text { Ibid. }\end{array}$ 
adil dan tidak adil. Orang yang mempelajari masalah hukum kurang senang dengan ketidakpastian ini. Itu akibat dari adanya anggapan hukum itu harus pasti (certum) untuk menjamin kehidupan bersama dan menghindari terjadinya chaos. Penegasan dari kepastian hukum itu dicapai dengan membentuk undang-undang (positifisasi). Kesimpulannya adalah bahwa dalam hukum yang sebenarnya dua segi disatukan: hukum adalah hukum yang adil dan pasti. Bila salah satu segi berkekurangan, hukum itu kehilangan artinya sebagai hukum. ${ }^{19}$

Hal ini dapat peneliti jelaskan secara sederhana dengan mengkomparasikan relativitas hukum yang pasti dengan hukum yang adil yaitu manusia yang secara realitas dibentuk dari dua komponen yang berbeda tapi saling dependensi; yaitu hubungan antara komponen jiwa dan raga. Memang benar adanya bahwa badan tanpa jiwa tidak bermakna, dan di sisi lain jiwa tidak dapat soliter. Jiwa hanya bisa eksis bila menyatu dengan raga membentuk manusia yang hidup. Namun persatuan dua hal yang berbeda ini, tidak lantas bisa disamakan. Baik jiwa maupun raga tetap memperlihatkan segi yang beda dalam eksitensi manusia.

Dengan menerima hukum alam sebenarnya diterima kriteria untuk menilai apa hukum yang sungguh menurut prinsip keadilan. Hukum semacam ini biasanya disebut hukum alam. Asal diketahui bahwa menganut hukum alam sekarang bukan berarti bahwa seluruh teori hukum alam dihadirkan kembali. Yang diperlukan hanya inspirasinya dihidupkan kembali agar bermanfaat bagi jaman sekarang yakni bahwa peraturan tersebut harus disusun dengan prinsip-prinsip keadilan supaya dapat menjadi hukum yang benar. ${ }^{20}$

\section{Rekonstruksi Asas Legalitas}

Eksistensi Asas Legalitas menyisakan polemik dalam hal penegakan hukum (law enforcement). Dalam konsepsi Negara Hukum, eksistensi Asas Legalitas adalah primaritas sifatnya, namun Asas Legalitas harus ada eksepsionalitas dalam memandang kejahatan.

Atas dasar keterbatasan asas legalitas tersebut sehingga dipandang perlu untuk merekonstruksi kembali rumusanya menjadi "tiada perbuatan pidana tanpa ada pidana menurut perundang-undangan pidana dan hukum yang hidup dalam masyarakat (living law)”. Rumusan ini yang ideal karena mengakomodir sifat melawan hukum formil maupun materil.

Dalam ilmu hukum pidana, pemidanaan terhadap suatu perbuatan harus memenuhi syarat-syarat pemi-

19 Heinrich A.Rommen, The Natural Law (St Louis 1947 ) 113

$20 \quad$ Ibid. 279. 
danaan. Syarat-syarat pemidanaan tersebut berkaitan dengan penilaian terhadap aspek perbuatan maupun sikap batin pelakunya. Dari aspek perbuatan (actus reus) diisyaratkan bahwa perbuatan tersebut harus melawan hukum dan tidak ada alasan pembenar yang menghapus sifat melawan hukum perbuatan tersebut. ${ }^{21}$

Syarat ini merupakan konsekwensi berlakunya asas legalitas. Sedangkan dari aspek sikap batin pelakunya (mens rea) diisyaratkan bahwa pada pelakunya ada kemampuan bertanggungjawab, ada kesalahan, dan tidak ada alasan pemaaf yang menghapus kesalahan tersebut. Syarat ini merupakan konsekwensi dari dianutnya asas culpabilitas. Semua syarat tersebut bersifat kumulatif dan harus dipenuhi (imperatif) dalam setiap pemidanaan.

Melawan hukum merupakan salah satu unsur mutlak dari suatu delik. Karena Pasal ayat (1) KUHP menganut ajaran legalitas formal (nulla poena sine lege) maka melawan hukum dalam hal ini diartikan secara sempit sebagai bertentangan dengan perundang-undangan. Artinya suatu perbuatan diklasifikasikan sebagai melawan hukum apabila bertentangan dengan undang-undang tertulis. Rumusan legalitas formal tersebut merupakan anak kandung dari aliran legisme yang diwarisi dari Code Penal Perancis yang bertujuan untuk memberikan perlindungan mutlak terhadap kepastian hukum sebagai reaksi dari ketidakpastian yang mutlak pada masa absolutisme. Dengan rumusan asas legalitas tersebut maka apabila ada perbuatan yang menurut masyarakat sangat tercela sehingga layak dipidana perbuatan tersebut tidak dapat dipidana apabila ternyata belum ada perundang-undangan yang merumuskan perbuatan tersebut sebagai delik.

Menurut ajaran sifat melawan hukum formal suatu perbuatan dikualifikasikan sebagai melawan hukum apabila bertentangan dengan perundangundangan tertulis, demikian juga sifat melawan hukum perbuatan tersebut hanya bisa dihapus dengan alasan pembenar yang dirumuskan dalam perundang-undangan tertulis sehingga hukum tidak tertulis sama sekali tidak mendapat tempat dalam hukum pidana.

Ajaran sifat melawan hukum materiil mengakui hukum tertulis sebagai hukum di samping perundang-undangan tertulis. Ajaran sifat melawan hukum materiil dalam fungsinya yang positif menyatakan bahwa hukum tidak tertulis dapat digunakan sebagai dasar untuk mengkualifikasi suatu perbuatan melawan hukum, artinya suatu perbuatan yang menurut masyarakat tidak patut atau bertentangan dengan rasa keadilan masyarakat (bertentangan dengan hukum tidak tertulis) dapat dinyatakan sebagai perbuatan melawan hukum dan oleh karenanya (apabila memenuhi syarat-syarat pemidanaan

$21 \quad$ R.B. Budi Prastowo, 'Delik Formil/Materiil, Sifat Melawan Hukum Formil/Materiil dan Pertanggungjawaban Pidana dalam Tindak Pidana Korupsi: Kajian Teori Hukum Pidana terhadap Putusan MK RI Perkara Nomor 003/PUU-IV/2006' (2006) 24 Jurnal Hukum Pro Justitia 212, 214. 
lainya) dapat dipidana. Ajaran ini tidak dianut dalam hukum pidana Indonesia karena jelas bertentangan dengan asas legalitas sebagaimana dirumuskan dalam Pasal 1 ayat (1) KUHP. Sedangkan ajaran sifat melawan hukum materill dalam fungsi yang negatif menyatakan bahwa hukum tidak tertulis dapat digunakan sebagi dasar untuk menghapus sifat melawan hukum suatu perbuatan yang sudah memenuhi rumusan delik dalam perundangundangan (tertulis). Dengan kata lain hukum tidak tertulis dapat berfungi sebagai alasan pembenar. Ajaran ini tidak bertentangan dengan asas legalitas dalam Pasal 1 ayat (1) KUHP karena yang dilarang dalam Pasal ayat (1) KUHP adalah menggunakan hukum tidak tertulis sebagai dasar pemidanaan, sedangkan dalam ajaran sifat melawan hukum materiil dalam fungsi yang negatif hukum tidak tertulis digunakan sebagai dasar untuk menghapuskan pidana. ${ }^{22}$

Basic idea "tiada perbuatan pidana tanpa ada pidana menurut perundangundangan pidana dan hukum yang hidup dalam masyarakat (living law)" adalah setiap perbuatan pidana selalu menimbulkan kerugian materil maupun imateril bagi korban. Merupakan sebuah keharusan bahwa setiap pelaku perbuatan pidana dipidana. Oleh karena itu dalam hal ini Asas Legalitas itu harus bersifat kompromi. Asas Legalitas harus extrovertif.
Kelemahan landasan ontologis dan aksiologis serta teleologis Asas Legalitas disebabkan bangunan Asas Legalitas didasarkan pada rumusan "nullum crimen sine poena legali" (tiada kejahatan tanpa pidana/hukuman menurut undang-undang). Dalam hal terjadinya crimina extra ordinaria (strafwaardig) karena menimbulkan kerugian bagi korban, rumusan ini hanya membangun relativitas antara perbuatan pidana dengan undang-undang pidana dan antara penguasa dengan pelaku dengan memberikan nilai manfaat kepada pelaku perbuatan (offender oriented). Inilah yang oleh penulis disebut keterbatasan pada aspek aksiologis substansi.

Dalam perspektif yang lain yakini dari sisi victims orientied, untuk dan atas nama perlindungan korban, terhadap semua perbuatan yang merugikan korban, harus dituntut dan dipidana. Orientasi terhadap kepentingan korban dibangun di atas gagasan "tiada perbuatan pidana tanpa ada pidana menurut perundang-undangan pidana dan hukum yang hidup dalam masyarakat (living law)". Gagasan ini akan membentuk hukum pidana yang akan menuntut dan memidana semua perbuatan pidana baik mala prohibita maupun crimina extra ordinaria dengan alasan bahwa semua perbuatan tersebut merupakan tindakan yang selalu merugikan korban. ${ }^{23}$

\footnotetext{
$22 \quad$ Ibid.

23 Deni Setyo B.Y., Dekonstruksi Asas Legalitas Hukum Pidana: Sejarah Asas Legalitas dan Gagasan Pembaharuan Filosofis Hukum Pidana (Setara Press 2014) 192-193.
} 
Gagasan "tentang tiada perbuatan pidana tanpa ada pidana menurut perundang-undangan pidana dan hukum yang hidup dalam masyarakat (living law)" yang berimplikasi pada victim oriented ternyata sudah ada secara faktual. Beberapa dekade yang lalu, enam (6) tahun setelah bangsa Indonesia merdeka tepatnya tahun 1951 pemerintah mengeluarkan sebuah undang-undang, yaitu Undang-Undang Darurat Republik Indonesia Nomor 1 Tahun 1951 (UU Drt 1951) tentang Pengadilan Swapraja. Pada Pasal 5 ayat (3) butir b menentukan "hakim menjatuhkan pidana penjara maksimum tiga (3) bulan dan/atau denda paling banyak lima ratus rupiah bagi perbuatan yang menurut hukum yang hidup (living law) dan harus dianggap sebagai delik yang belum ada padanannya dalam KUHP”. Ketentuan Pasal 5 ayat (3) butir b undangundang tersebut menurut penulis berbicara tentang keharusan menghukum crimina extra ordinaria karena bertentangan dengan living law (sifat melawan hukum materiil). Menurut peneliti juga penerbitan UU Darurat tersebut karena adanya pandangan bahwa Asas Legalitas dalam KUHP sudah tidak dipandang sebagai sesuatu yang primaritas lagi.

Gagasan "tentang tiada perbuatan pidana tanpa ada pidana menurut perundang-undangan pidana dan hukum yang hidup dalam masyarakat (living law)" juga pernah diterapkan dalam praktik peradilan bangsa Indonesia, yaitu pada peristiwa tindak pidana Terorisme tanggal 12 Oktober tahun 2002 di Bali yang menelan korban 202 jiwa dari 21 negara. Pada persitiwa tersebut pemerintah bertindak melawan hukum (Asas Legalitas) untuk menegakan hukum. Wujud nyata melawan hukum tersebut oleh pemerintah adalah dengan memberlakukan secara surut Asas Legalitas (retroactive) dengan dikeluarkannya PERPU No. 1 Tahun 2002 tentang Pemberantasan Tindak Pidana Terorisme yang kemudian ditetapkan menjadi UU No.15 Tahun 2003 tentang Pemberantasan Tindak Pidana Terorisme. Perbuatan melawan hukum tersebut semata-mata untuk memberikan jaminan perlindungan terhadap korban (Law enforcement).

Jadi bisa disimpulkan, bahwa tindakan pemerintah untuk membatasi primaritas Asas Legalitas adalah tindakan sewenang-sewenang. Yang perlu disoroti disini adalah bukan semata-mata tindakan sewenangwenang tetapi bagaimana kebijaksanaan (sofia) pemerintah untuk menegakkan hukum walaupun terkesan melawan hukum. Selain itu, di dalam hukum ada prinsip-prinsip tertentu yang memiliki gradasi lebih tinggi dari sekedar kepastian hukum yang harus diprioritaskan. Prinsip-prinsip tersebut adalah prinsip-prinsip umum keadilan yang berisikan moralitas. Atas nama moralitas yang berisikan nilai-nilai kebenaran dan keadilan, sehingga tindakan melawan hukum (rectroactif) sangat dibenarkan.

Gagasan "tiada perbuatan pidana tanpa ada pidana menurut perundangundangan pidana dan hukum yang hidup 
dalam masyarakat (living law)" menurut peneliti juga sejalan dengan terma dalam hukum alam klasik yang berbunyi there exist no right to violate a right (bukanlah hak namanya kalau kita melanggar hak orang lain). Ini menandakan bahwa kalau melanggar hak orang lain berati siap juga pada akirnya haknya akan dilanggar orang lain pula.

Gagasan "tiada perbuatan pidana tanpa ada pidana menurut perundangundangan pidana dan hukum yang hidup dalam masyarakat (living law)" yang berimplikasi pada victim oriented sudah diimpikan oleh bangsa Indonesia sejak tahun 1964 dalam KUHP baru, tetapi belum diwujudkan hingga hari ini. Walaupun UUHP baru belum dapat diwujudkan, tetapi sekarang telah ada RUU KUHP tahun 2015 yang secara implisit telah memperhatikan gagasan nullum crimen sine poena. Hal tersebut dapat ditemukan dalam buku Kesatu Tentang Ketentuan Umum RUU KUHP Pasal 2 ayat (1) yang menentukan bahwa:

"Ketentuan sebagaimana dimaksud dalam Pasal 1 ayat (1) tidak mengurangi berlakunya hukum yang hidup dalam masyarakat yang menentukan bahwa seseorang patut dipidana walaupun perbuatan tersebut tidak diatur dalam perundangan-undangan "

Ayat 2 menentukan:

"Berlakunya hukum yang hidup dalam masyarakat sebagaimana dimaksud pada ayat (1) sepanjang sesuai dengan nilainilai yang terkandung dalam pancasila, HAM, dan prinsip-prinsip hukum umum yang diakui oleh masyarakat bangsabangsa."

Dan dalam buku kedua (2) bab XXXVI Pasal 756 ayat (1) menentukan bahwa:
"Setiap orang yang melakukan perbuatan yang menurut hukum yang tidak tertulis dinyatakan sebagai perbuatan yang dilarang dan diancam dengan sanksi pidana adalah tindak pidana. "

Dari rumusan Pasal 2 ayat jo Pasal 756 ayat (1) RUU KUHP tersebut di atas dapatlah kita menyatakan bahwa ide dasar dari rumusan pasal tersebut adalah sejalan dengan apa yang digagas peneliti tentang "tiada perbuatan pidana tanpa pidana menurut perundangundangan pidana dan hukum yang hidup dalam masyarakat (living law)" menindak pelaku tindak pidana yang sifatnya crimina extra ordinaria berdasarkan prinsip moral dan prinsip umum keadilan.

Penyusunan Kitab Undang-Undang Hukum Pidana Nasional yang baru untuk menggantikan KUHP peninggalan pemerintah kolonial Belanda dengan segala perubahanya merupakan salah satu usaha dalam rangka pembangunan hukum nasional. Usaha tersebut dilakukan secara terarah dan terpadu agar dapat mendukung pembangunan nasional di berbagai bidang, sesuai dengan tuntutan pembangunan serta tingkat kesadaran hukum dan dinamika yang berkembang dalam masyarakat.

Dalam perkembangannya, makna pembaharuan KUHP nasional yang semula semata-mata diarahkan kepada misi tunggal mengandung dekolonisasi KUHP dalam bentuk rekodifikasi dalam perjalanan sejarah bangsa pada akhirnya juga mengandung pelbagai misi yang lebih luas sehubungan dengan perkembangan nasional maupun internasional. 
Berbagai misi tersebut diletakkan dalam kerangka politik hukum yang tetap memandang perlu penyusunan hukum pidana dalam bentuk kodifikasi dan unifikasi yang dimaksudkan untuk menciptakan dan menegakkan konsistensi, keadilan, kebenaran, ketertiban, dan kepastian hukum dengan memperhatikan keseimbangan antara kepentingan nasional, kepentingan masyarakat, dan kepentingan individu, dalam negara RI berlandaskan Pancasila dan UUD NRI Tahun 1945. ${ }^{24}$

Sejalan dengan misi tersebut Teguh Prasetyo menyatakan:

Pancasila haruslah benar-benar dipergunakan sebagai sumber dari segala sumber hukum atau sumber utama hukum, kesepakatan pertama, sistem hukum positif Indonesia. Modelmodel penyelanggaraan hukum, seperti yang dikembangkan di Barat yang agaknya sering menjadi panutan, tanpa menyertakan bagaimana basis sosial serta asal-usul sosialnya dikaji dan dikembangkan atau disesuaikan dengan filosofis, sosiologis, dan sosiologis nasional. Model-model atau konsep barat yang sebelumnya diterima seolah-olah sesuatu yang absolut normatif disesuaikan dengan jiwa bangsa atau volkgeist. ${ }^{25}$

\section{PENUTUP}

Artikel ini memberi sebuah konklusi bahwa ternyata kalau kita bicara tentang hukum dalam konteks penegakan hukum kira-kira aspek mana yang harus kita kedepankan Supremasi hukum atau Supremasi undang-undang, sisi positif hukum atau negatif dari hukum. Asas Legalitas yang baru (hasil rekonstruksi) telah mewakili sisi positif dari hukum dan sepadan dengan semangat bangsa Indonesia untuk segera memiliki Undang-Undang Hukum Pidana baru tanpa harus bergantung dengan Undang-Undang Hukum Pidana milik negara lain yang pernah menjajah bangsa Indonesia.

\section{DAFTAR BACAAN}

\section{Buku}

Bellefroid, J.H.P., et.al., Inleiding tot de Rechtwetenschap in Nederlands (Utrecht 1952).

Bemmelen, Van, Ons Strafrecht: Algemeen del het Materiel Strafrecht (H.D. Tjeenk Willink 1971).

Dijk, P. Van, et.al., Van Apeldoorn's Inleiding tot de Studie van het Nederlands Recht (W.E.J. TjeenkWillink 1985).

Fletcher, George P., Basic Concepts of Criminal Law (Oxford University Press 1998).

Huijbers, Theo, Filsafat Hukum dalam Lintasan Sejarah (Kanisius 1982).

Marzuki, Peter Mahmud, Pengantar Ilmu Hukum (Kencana Prenada Media Group 2013).

Moeljatno, Asas-Asas Hukum Pidana (Rineka Cipta 2000).

Prasetyo, Teguh, Keadilan Bermartabat: Perspektif Teori Hukum (Nusa Media 2015).

Rommen, Heinrich A., The Natural Law (St Louis 1947).

24 Penjelasan RUU KUHP Tahun 2012

25 Teguh Prasetyo, Keadilan Bermartabat: Perspektif Teori Hukum (Nusa Media 2015)183. 
Schaffmeister, D., et.al., Hukum Pidana (Liberty 1995).

Setyo B.Y., Deni, Dekonstruksi Asas Legalitas Hukum Pidana: Sejarah Asas Legalitas dan Gagasan Pembaharuan Filosofis Hukum Pidana (Setara Press 2014).

Soekanto, Soerjono, \& Sri Mamudji, Penelitian Hukum Normatif: Suatu Tinjauan Singkat (Rajawali Press 1990).

\section{Jurnal dan Makalah}

Hiarej, Eddy O.S., 'Asas Legalitas dan Perkembangannya dalam Hukum Pidana' (Pelatihan Hukum Pidana dan Kriminologi, Universitas Gadjah Mada, Yogyakarta, 2014).

Prastowo, R.B. Budi, 'Delik Formil/ Materiil, Sifat Melawan Hukum Formil/Materiil dan Pertanggungjawaban Pidana dalam Tindak Pidana Korupsi: Kajian Teori Hukum Pidana terhadap Putusan MK RI Perkara Nomor 003/PUUIV/2006' (2006) 24 Jurnal Hukum Pro Justitia 212. 
